\title{
ANALISIS TITIK IMPAS USAHATANI KUBIS PUTIH (Brassica oleracea)
}

(Studi Kasus di Desa Cibeureum Kecamatan Sukamantri Kabupaten Ciamis)

\author{
Oleh : \\ Andi Maulana ${ }^{1}$, Dini Rochdiani ${ }^{2}$, Muhamad Nurdin Yusuf ${ }^{3}$ \\ ${ }^{13}$ Fakultas Pertanian Universitas Galuh \\ ${ }^{2}$ Fakultas Pertanian Universitas Padjadjaran
}

\begin{abstract}
Abstrak
Penelitian ini bertujuan untuk mengetahui besarnya: (1) Biaya yang di keluarkan dalam usahatani kubis per hektar per satu musim tanam di Desa Cibeureum, (2) Pendapatan dalam usahatani kubis per hektar per satu musim tanam di Desa Cibeureum, (3) Titik impas dalam usahatani kubis per hektar per satu musim tanam di Desa Cibeureum. Jenis penelitian yang digunakan dalam penelitian ini adalah metode survai, dengan mengambil kasus di Desa Cibeureum Kecamatan Sukamantri Kabupaten Ciamis. Jumlah responden diamibil dari semua petani kubis sebanyak 20 orang petani dengan menggunakan metode sampling jenuh atau sensus.

Hasil penelitian ini memperlihatkan bahwa : 1) Besarnya biaya yang dikeluarkan dalam usahatani kubis per hektar per satu musim tanam di Desa Cibeureum rata-rata sebesar Rp 1.778.876,13. 2) Besarnya pendapatan usahatani kubis per hektar per satu musim tanam di Desa Cibeureum rata-rata sebesar Rp 1.221.125,86. 3) Besarnya titik impas pada usahatani kubis per hektar per satu musim tanam di Desa Cibeureum rata-rata sebagai berikut: a) Titik impas penerimaan adalah Rp 683.846,84. b)Titik impas volume produksi adalah 227,94 kilogram. c) Titik impas luas lahan adalah 0,02/hektar. d) Titik impas harga adalah Rp 592,95.
\end{abstract}

Kata Kunci : Titik impas, Usahatani, Kubis putih

\section{PENDAHULUAN}

Komoditas hortikultura merupakan komoditas potensial yang mempunyai nilai ekonomi tinggi dan memiliki potensi untuk terus dikembangkan. Dari sisi permintaan pasar, jumlah penduduk yang besar, kenaikan pendapatan, dan berkembangnya pusat kota-industri-wisata, serta liberalisasi perdagangan merupakan faktor utama yang mempengaruhi permintaan. Sementara itu, dari sisi produksi, luas wilayah Indonesia dengan keragaman agroklimatnya memungkinkan pengembangan berbagai jenis tanaman baik tanaman hortikultura tropis maupun hortikultura subtropis, yang mencakup 323 jenis komoditas, yang terdiri atas 60 jenis komoditas buah-buahan, 80 jenis komoditas sayuran, 66 jenis komoditas biofarmaka dan 117 jenis komoditas tanaman hias (Ditjen Hortikultura, 2008).

Sayuran merupakan salah satu komoditas hortikultura yang berkembang pesat di Indonesia. Selain sebagai komoditas yang esensial bagi pemenuhankebutuhan dasar manusia dalam menyediakan vitamin dan mineral, sayuran juga telah memberikan kontribusi sebesar 38,07 persen pada tahun 2008 terhadap sub sektor hortikultura. Saat ini, kecenderungan minat masyarakat terhadap sayuran terus meningkat, hal tersebut merupakan adanya akibat dari pola hidup sehat yang telah menjadi gaya hidup masyarakat. Perubahan paradigma menuju pemahaman hidup yang sehat tidak hanya memerlukan protein dan kalori saja, tetapi juga vitamin dan mineral yang terkandung dalam sayuran dan buah-buahan untuk menjalani pola konsumsi gizi yang seimbang. Tingkat konsumsi sayuran masyarakat Indonesia mengalami peningkatan, dimana pada tahun 2005 sebesar 35,30 kilogram kapita per tahun, kemudian tahun 2006 sebesar 34,06 kilogram per kapita per tahun dan tahun 2007 sebesar 40,90 kilogram per kapita per tahun serta tahun 2008 meningkat sebesar 51,31 kilogram per kapita per tahun (Departemen Pertanian, 2009).

Salah satu komoditas unggulan sayuran yang banyak dijadikan sebagai komoditi utama oleh petani untuk meningkatkan pendapatan kubis. Kubis (Brassica) merupakan tanaman sayuran subtropik yang banyak ditanam di Eropa dan Asia, pertumbuhan vegetatif terjadi pada tahun pertama dan pertumbuhan generatif (berbunga dan berbiji) pada tahun berikutnya (Mulyono, 2007).

Kabupaten Ciamis merupakan salah satu wilayah penghasil kubis, hal ini dapat dilihat dari potensi kubis di Kabupaten Ciamis memiliki luas panen 5,2 hektar dengan produksi 324 kuintal dan produktivitas mencapai 156,44 kuintal per hektar. Kecamatan Sukamantri memiliki produktivitas kubis tertinggi di Kabupaten Ciamis, luas panen 9 hektar dengan produksi 265 kuintal dan produktivitas 91,37 kuintal per hektar. Produksi kubis di Kecamatan Sukamantri diusahakan oleh

Halaman | 67 
Jurnal Ilmiah Mahasiswa AGROINFO GALUH

Volume 3 Nomor 2, Januari 2017

petani di 3 desa, yaitu: Sukamantri, Cibeureum, dan Sindanglaya. Desa Cibeureum merupakan desa yang menghasilkan kubis tertinggi di Kecamatan Sukamantri sebanyak 200 kuintal. (Dinas Pertanian Tanaman Pangan Kabupaten Ciamis).

Harga kubis ditingkat petani selalu berfluktuasi dari $\mathrm{Rp} 1.500$,-sampai dengan $\mathrm{Rp}$ 4.000,- per kilogram, tergantung pada musim panen. Pada musim panen besar harganya relatif rendah sedangkan pada hari-hari besar seperti hari raya serta diluar musim harganya relatif sangat tinggi.

Walaupun demikian petani di Desa Cibeureum sangat bergantung pada usahatani kubis, mengingat kubis sangat dibutuhkan oleh masyarakat besar untuk dijadikan sebagai sayuran yang kaya akan vitamin dan mineral. Ada pula kendala yang sering timbul pada kubis, yaitu serangan hama juga harga yang berfluktuasi.

Hama dan penyakit yang menyerang berpengaruh terhadap suatu hasil produktivitas dan harga kubis yang selalu berfluktuasi menyebabkan tidak menentunya pendapatan bahkan dapat berdampak pada kerugian yang harus ditanggung petani.

\section{Identifikasi Masalah}

Masalah yang diidentifikasi dalam penelitian ini adalah sebagai berikut:

1) Berapa besarnya biaya yang dikeluarkan petani per hektar dalam satu kali musim tanam?

2) Berapa besarnya penerimaan dan pendapatan yang diperoleh petani per hektar dalam satu kali musim tanam?

3) Berapa besarnya titik impas usahatani kubis per hektar dalam satu kali musim tanam?

\section{Tujuan Penelitian}

Tujuan penelitian ini adalah untuk mengetahui :

1) Biaya yang diperoleh petani per hektar dalam satu kali musim tanam?

2) Penerimaan dan pendapatan yang diperoleh petani per hektar dalam satu kali musim tanam?

3) Titik impas pada usahatani kubis per hektar dalam satu kali musim tanam?

\section{TINJAUAN PUSTAKA}

\section{Kubis Putih (Brassica oleracea)}

Kubis adalah sayuran yang berlapis-lapis dalam kondisi hari diterangi matahari panjang seperti yang ditemukan di garis lintang utara di musim panas kubis dapat tumbuh lebih besar beberapa rekor dibahas pada akhir bagian sejarah. Kubis putih atau kol merupakan tumbuhan yang termasuk dalam kelompok botrytis dari jenis brasiica oleracea, suku brassicaceae sebagai sayuran, tumbuhan ini lazim dikenal dengan sebutan kembang kol yang merupakan terjemahan harafiah dari bahasa Belanda bloemkool. Kubis juga merupakan sumber vitamin dan mineral yang dapat memenuhi kebutuhan tubuh manusia (Mulyono, 2007).

Kepala kubis umumnya diambil selama tahun pertama dari daur hidup tanaman tetapi tanaman yang dimaksudkan untuk benih dibiarkan tumbuh tahun kedua. Tanaman kubis ini berasal dari Eropa dan Asia kecil, terutama tumbuh di daerah Great Britain dan Mediterania. Asal-usul tanaman kubis budidaya diduga berasal dari kubis liar yang tumbuh di sepanjang pantai Laut Tengah, Inggris, Denmark, dan sebelah Utara Perancis Barat serta pantai Glamorgan. Pada mulanya kubis liar tumbuh menahun dan dua musin, kemudian oleh orang Eropa dipanen biji-bijinya. Dari sejumlah 5000 tanaman diperoleh 70.000 biji kubis yang selanjutnya ditanam kembali. Pada tahapan ini diketemukan turunan tanaman kubis yang akarakarnya membengkak dan daunnya dapat dimanfaatkan sebagai bahan makanan (Mulyono, 2007).

Tanaman kubis merupakan tanaman semusim (anual) yang berbentuk perdu, dengan susunan organ tubuh utama batang daun, bunga, buah, biji dan akar, sistem perakaran tanaman ini relatif dalam yang dapat menembus permukaan tanah yang kedalamannya antara 20-30 cm (Mulyono, 2007).

\section{METODE PENELITIAN \\ Jenis Penelitian}

Jenis penelitian yang digunakan dalam penelitian ini adalah metode survai di Desa Cibeureum Kecamatan Sukamantri Kabupaten Ciamis. Metode survai yaitu penelitian yang dilakukan pada populasi besar maupun kecil, data yang dipelajari diambil dari populasi tersebut sehingga dapat ditemukan kejadian-kejadian relatif, distribusi dan hubungan antar variabel, sosiologis maupun psikologis (Wirartha, 2006).

\section{Teknik Pengumpulan Data}

Jenis data yang dikumpulkan dalam penelitian ini meliputi data primer dan data sekunder.

\section{Teknik Penarikan Sampel}

Jumlah sampel ditentukan menggunakan metode sampling jenuh atau sensus, dimana seluruh petani kubis di Desa Cibeureum Kecamatan Sukamantri dijadikan sampel semua yaitu sebanyak 20 orang.

\section{Rancangan Analisis Data}

Data yang diperoleh dianalisis dengan menggunakan analisis usahatani. Untuk menganalisis usahatani kubis di Desa Cibeureum Kecamatan Sukamantri Kabupaten Ciamis digunakan rumus sebagai berikut:

1) Analisis Biaya 
Analisis Titik Impas Usahatani Kubis Putih (Brassica Oleracea)

(Studi Kasus Di Desa Cibeureum Kecamatan Sukamantri Kabupaten Ciamis)

ANDI MAULANA ${ }^{1}$, DINI ROCHDIANI ${ }^{2}$, MUHAMAD NURDIN YUSUF ${ }^{3}$

Menurut (Suratiyah, 2006) untuk menghitung besarnya biaya total (Total Cost) diperoleh dengan cara menjumlahkan biaya tetap (Fixed Cost/ FC) dan biaya variabel (Variable Cost) dengan rumus:

Dimana :

$$
\mathrm{TC}=\mathrm{TFC}+\mathrm{TVC}
$$

TC $=$ Total Cost (Biaya Total)

TFC = Fixed Cost (Biaya Tetap Total)

TVC = Variable Cost (Biaya Variabel Total)

2) Analisis Penerimaan

Menurut (Suratiyah, 2006) secara umum perhitungan penerimaan total (Total Revenue/TR) adalah perkalian antara jumlah produksi (Y) dengan harga jual (Py) dan dinyatakan dengan rumus sebagai berikut:

$$
\mathrm{TR}=\mathrm{Py} \text {. Y }
$$

Dimana :

$\mathrm{TR}=$ Total Revenue (Penerimaan Total)

$\mathrm{Py}=$ Harga produk

$\mathrm{Y}=$ Jumlah produksi

3) Analisis Pendapatan

Menurut (Suratiyah, 2006) pendapatan adalah selisih antara penerimaan (TR) dengan biaya total (TC) dan dinyatakan dengan rumus:

$$
\mathrm{Pd}=\mathrm{TR}-\mathrm{TC}
$$

Dimana :

$\mathrm{Pd}=$ Pendapatan

$\mathrm{TR}=$ Total Revenue $($ Penerimaan Total $)$

$\mathrm{TC}=$ Total Cost $($ Biaya Total $)$

4) Analisis titik impas

Untuk mengetahui titik impas (Break Even Point) dihitung dengan menggunakan rumus sebagai berikut (Suratiyah, 2006) :

a.Titik impas penerimaan (Rp) :

Biaya tetap total

$\mathrm{BEP}$ penerimaan $(\mathrm{BEPnp})=$

$$
\text { 1- } \frac{\text { Biaya variabel }}{\text { Nilai penjualan }}
$$

b.Titik impas volume produksi $(\mathrm{Rp})$ :

$\mathrm{BEP}$ volume produksi $(\mathrm{BEPvp})=\frac{\mathrm{BEP} \text { penerimaan }(\mathrm{Rp})}{\operatorname{Harga}(\mathrm{Rp}) /(\mathrm{Kg})}$

c.Titik impas luas lahan (ton/ha) :

BEP volume produksi

$\mathrm{BEP}$ luas lahan $=\frac{\text { BEP volume produk }}{\text { Produktivitas lahan }}$

d.Titik impas harga $(\mathrm{Rp}) /(\mathrm{Kg})$ :

Titik impas harga $(\mathrm{Rp}) /(\mathrm{Kg})=\frac{\mathrm{BEP} \text { penerimaan }(\mathrm{Rp})}{\text { BEP volume produksi }(\mathrm{Kg})}$

\section{Tempat dan Waktu Penelitian}

Penelitian ini dilaksanakan di Desa Cibeureum Kecamatan Sukamantri Kabupaten Ciamis. waktu pelaksanaan penelitian yaitu pada bulan maret sampai bulan juni 2016.

\section{HASIL DAN PEMBAHASAN \\ Identitas Responden}

Indikator yang digunakan identitas responden meliputi beberapa aspek antara lain pengalaman berusaha, jumlah tanggungan keluarga, umur, tingkat pendidikan, luas lahan yang digarap.

\section{Pengalaman Berusahatani Responden}

Berdasarkan hasil penelitian, pengalaman responden dalam melakukan usahatani kubis di Desa Cibeureum sebagian besar lebih dari 11 tahun yaitu sebanyak 16 orang dan yang kurang dari 11 tahun sebanyak 4 orang.

\section{Tanggungan Keluarga Responden}

Berdasarkan hasil penelitian menunjukkan bahwa umumnya responden memiliki tanggungan keluarga sebanyak 3-5 orang atau 65,00 persen.

\section{Umur Responden}

Umur responden berkisar antara 37-50 tahun, dengan demikian seluruh responden berusia produktif.

\section{Tingkat Pendidikan}

Keadaan tingkat pendidikan responden umumnya adalah tamatan Sekolah Menengah Pertama (SMP) yaitu sebanyak 11 responden, sedangkan yang lainnya yaitu tamatan Sekolah Dasar (SD) yaitu sebanyak 5 responden, tamatan Sekolah Lanjutan Tingkat Atas (SLTA) sebanyak 4 responden.

5. Luas Lahan Usahatani Kubis Putih yang di garap

Berdasarkan hasil yang diperoleh dengan wawancara langsung dilapangan terhadap responden, bahwa pada umumnya responden menggarap lahan usahatani kubis berkisar antara 0,1 hektar atau $1.000 \mathrm{~m}^{2}$ dari luas lahan keseluruhan seluas 2 hektar.

\section{Analisis Usahatani Kubis Putih (Brassica} oleraceaL.)

\section{A. Analisis Biaya}

1) Biaya Total

Biaya total yang dihitung dalam penelitian ini meliputi biaya tetap total ditambah dengan biaya variabel total. Hasil perhitungan memperlihatkan bahwa rata-rata besarnya biaya total yang dikeluarkan petani kubis di Desa Cibeureum adalah sebesar Rp $1.778 .876,13$ per satu kali musim tanam.

2) Biaya Tetap

Biaya tetap yang dihitung dalam penelitian ini meliputi biaya penyusutan alat, dan biaya sewa lahan. Besarnya biaya tetap yang di keluarkan masing-masing responden berbeda-beda. Hasil perhitungan rata-rata biaya tetap usahatani kubis sebesar Rp 362.438,83 per satu kali musim tanam.

Halaman | 69 
Jurnal Ilmiah Mahasiswa AGROINFO GALUH

Volume 3 Nomor 2, Januari 2017

Biaya penyusutan alat dipengaruhi oleh jenis dan banyaknya alat pertanian yang digunakan dan dimiliki petani dalam usahatani kubis tersebut. Jenis alat yang digunakan meliputi : cangkul, parang, sprayer, garpu, timbangan, golok, mulsa, Power Sprayer, selang/paralon dan ember. Ratarata penyusutan alat pada usahatani kubis di Desa Cibeureum yaitu sebesar Rp 257.964,28 per satu kali musim tanam.

Biaya sewa lahan yang dikeluarkan petani kubis dalam penelitian ini sebesar Rp 1.000.000,- per hektar. Dengan demikian, rata-rata biaya sewa lahan yang dikeluarkan oleh petani kubis adalah sebesar Rp 100.000,- per satu kali musim tanam.

\section{3) Biaya Variabel}

Biaya variabel yang dihitung dalam penelitian ini meliputi upah tenaga kerja, benih, pupuk organic berupa kotoran ayam, pupuk NPK, ponska, ZA, fungisida, dan insektisida. Hasil perhitungan memperlihatkan bahwa rata-rata besarnya biaya variabel yang dikeluarkan petani kubis sebesar Rp $1.416 .437,3$ per satu kali musim tanam.

Dalam melakukan kegiatan usahatani kubis membutuhkan tenaga kerja, baik yang berasal dari tenaga kerja dalam keluarga maupun dari luar keluarga petani kubis. Sistem pembayaran sesuai dengan upah yang berlaku di daerah penelitian yang dibayar secara tunai. Dan sistem kerja di daerah penelitian untuk usahatani kubis dilakukan secara borongan dengan upah Rp 25.000,-sampai Rp 35.000,- per orang. Rata-rata biaya tenaga kerja yang dikeluarkan oleh petani kubis adalah sebesar Rp 638.762,3 persatu kali musim tanam.

Tabel 1. Rata-rata Biaya pada Usahatani Kubis per Satu Kali Musim Tanam

\begin{tabular}{|l|l|}
\hline Komponen Biaya & Jumlah \\
\hline A. Biaya Tetap & \\
\hline - Penyusutan Alat & $257.964,28$ \\
\hline - Sewa Lahan & 100.000 \\
\hline - Bunga modal & $\begin{array}{l}4.474,55 \\
(1,25 \%)\end{array}$ \\
\hline Jumlah & $\mathbf{3 6 2 . 4 3 8 , 8 3}$ \\
\hline B. Biaya Variabel & \\
\hline - Benih & 136.500 \\
\hline - Pupuk Organik KotoranAyam & 136.425 \\
\hline - Pupuk NPK & 94.500 \\
\hline - Ponska & 49.000 \\
\hline - ZA & 562.500 \\
\hline - Fungisida & 180.000 \\
\hline - Insektisida & 125.000 \\
\hline - Tenaga Kerja & $638.762,3$ \\
\hline Jumlah & $\mathbf{1 . 4 1 6 . 4 3 7 , 3}$ \\
\hline Jumlah biaya total & $\mathbf{1 . 7 7 8 . 8 7 6 , 1 3}$ \\
\hline
\end{tabular}

Tabel 1 menunjukkan bahwa besarnya rata-rata biaya pada usahatani kubis adalah sebesar Rp 1.778.876,13 terdiri dari biaya tetap sebesar $\mathrm{Rp}$ $362.438,83$ dan biaya variabel sebesar $\mathrm{Rp}$ $1.416 .437,3$

\section{B. Analisis Pendapatan}

Pendapatan merupakan selisih antara penerimaan dengan biaya total yang dikeluarkan, sedangkan penerimaan merupakan hasil perkalian antara harga jual kubis dengan banyaknya kubis yang dihasilkan. Berdasarkan hasil penelitian harga jual kubis pada saat penelitian adalah $\mathrm{Rp}$ 3.000,- per kilogram, sedangkan rata-rata kubis yang dihasilkan per satu kali musim tanam sebesar 1.000 kilogram, sehingga didapat penerimaan sebesar Rp 3.000.000,- dengan biaya yang dikeluarkan adalah sebesar $\mathrm{Rp}$ 1.778.876,13 sehingga diperoleh pendapatan sebesar Rp 1.221.125,86 per satu kali musim tanam.

C. Analisis Titik Impas (BEP)

\section{1) Analisis Titik Impas Penerimaan (BEPnp)}

Besar penerimaan minimum yang di terima petani agar usahatani kubis tidak dapat mengalami kerugian dapat diketahui dengan menggunakan rumus sebagai berikut (Suratiyah, 2006) :

Biaya tetap total

$$
\begin{aligned}
& \text { BEP penerimaan (BEPnp) }=\frac{\text { Biaya variabel }}{1-\frac{362.438,83}{\text { Nilai penjualan }}} \\
& \text { BEP penerimaan (BEPnp) }=\frac{1.416 .437,3}{3.000 .000} \\
& \text { BEP penerimaan (BEPnp) }=\frac{362438,83}{1-0,47} \\
& \text { BEP penerimaan (BEPnp) }=\frac{362.438,83}{0,53} \\
& =683.846,84
\end{aligned}
$$

Hasil perhitungan menunjukkan bahwa penerimaan minimum yang harus diterima dalam usahatani kubis agar tidak mengalami kerugian dalam satu kali musim tanam adalah sebesar Rp $683.846,84$

2) Analisis Titik Impas Volume Produksi.

Volume atau jumlah produksi minimum yang harus diperoleh untuk mencapai titik impas (break event point) dalam satu kali musim tanam, maka dapat dihitung menggunakan rumus sebagai berikut (Suratiyah,2006)

Halaman $\mid 70$ 
Analisis Titik Impas Usahatani Kubis Putih (Brassica Oleracea) (Studi Kasus Di Desa Cibeureum Kecamatan Sukamantri Kabupaten Ciamis) ANDI MAULANA ${ }^{1}$, DINI ROCHDIANI ${ }^{2}$, MUHAMAD NURDIN YUSUF ${ }^{3}$ 3.000.000,- per satu kali musim tanam, diperoleh dari hasil panen kubis sebanyak 1.000 kilogram dengan harga Rp 3.000,- per kilogram.

$$
\begin{aligned}
\text { BEP volume produksi (BEPvp) } & =\frac{\text { BEP penerimaan }(\mathrm{Rp})}{\operatorname{Harga}(\mathrm{Rp}) /(\mathrm{Kg})} \\
\text { BEP volume produksi }(\mathrm{BEPvp}) & =\frac{683.846,84}{3.000,-} \\
& =227,94 \text { kilogram. }
\end{aligned}
$$

\section{3) Analisis Titik Impas Luas Lahan.}

Luas lahan minimum usahatani kubis yang harus diusahakan petani agar petani tidak menderita kerugian maka dapat dihitung dengan rumus sebagai berikut (suratiyah, 2006) :

$$
\begin{aligned}
\text { BEP luas lahan } & =\frac{227,94 \text { kilogram }}{\text { Produktivitas lahan }} \\
\text { BEP luas lahan } & =\frac{10.000 \text { kilogram } / \text { hektar }}{} \\
& =0,02 \text { hektar. }
\end{aligned}
$$

Hasil perhitungan menunjukan bahwa luas minimum yang harus diusahakan seluas 0,02 hektar atau seluas 200 meter persegi.

\section{4) Analisis Titik Impas Harga.}

Harga jual minimum yang harus dipertahankan agar petani kubis tidak mengalami kerugian dapat dihitung menggunakan rumus sebagai berikut (suratiyah, 2006) :

$$
\text { Titik impas harga }(\mathrm{Rp}) /(\mathrm{Kg})=\frac{\text { Total biaya }(\mathrm{Rp})}{\text { Harga }(\mathrm{Rp})}
$$$$
\text { Rp 1.778.876,13 }
$$

$$
\begin{aligned}
\text { Titik impas harga }(\mathrm{Rp}) /(\mathrm{Kg}) & =\frac{\operatorname{Rp~3.000,-}}{} \\
& =\operatorname{Rp} 592,95
\end{aligned}
$$

Hasil perhitungan menunjukan bahwa harga jual minimum yang harus di pertahankan agar petani tidak mengalami kerugian adalah Rp 592,95 per kilogram. Secara grafik titik impas (BEP) usahatani kubis di Desa Cibeureum dapat dilihat pada gambar 2 .

\section{KESIMPULAN DAN SARAN \\ Kesimpulan}

Berdasarkan hasil dan pembahasan yang telah dilakukan dapat diambil kesimpulan:

1. Besarnya rata-rata biaya pada usahatani kubis putih di Desa Cibeureum Kecamatan Sukamantri Kabupaten Ciamis sebesar Rp 1.778.876,13 per satu kali musim tanam. Sedangkan penerimaannya adalah sebesar $\mathrm{Rp}$ Halaman | 71
2. Besarnya rata-rata pendapatan pada usahatani kubis putih di Desa Cibeureum Kecamatan Sukamantri Kabupaten Ciamis adalah sebesar Rp 1.221.125,86 per satu kali musim tanam.

3. Besarnya titik impas (break event point) pada usahatani kubis putih di Desa Cibeureum Kecamatan Sukamantri Kabupaten Ciamis terbagi menjadi 4 bagian meliputi :
a. Titik impas penerimaan adalah : $\mathrm{Rp}$ $683.846,84$
b. Titik impas volume produksi adalah : 227,94 kilogram
c. Titik impas luas lahan adalah : 0,02 per hektar
d. Titik impas harga adalah Rp 592,95

\section{Saran}

Berdasarkan kesimpulan diatas, maka disarankan agar kegiatan usahatani kubis putih di Desa Cibeureum Kecamatan Sukamantri Kabupaten Ciamis minimalnya petani harus berupaya untuk mempertahankan hasil minimum yang telah ditetapkan dari hasil jumlah produksi, luas lahan, harga dan penerimaan yang telah ditetapkan supaya kegiatan usahatani kubis tidak mengalami kerugian.

\section{DAFTAR PUSTAKA}

Agustina, S. 2011. Ilmu Usahatani. Universitas Brawijaya Press: Malang.

Anjayani dan Haryanto. 2009. Geografi SMA XI. Penerbit Cempaka Putih. Jakarta.

BP3K Kecamatan Sukamantri. Realisasi Luas Panen, Produksi dan Produktivitas Tanaman Kubis. 2015.

Darmawan, A. 2010. Panduan Praktikum Sistem Informasi Geografi. Jurusan Kehutanan Fakultas Pertanian Unila. Bandar Lampung.

Departemen Pertanian. 2009. Dasar - Dasar Penyuluhan Pertanian. Deptan. Jakarta.

Dinas Pertanian Tanaman Pangan Kabupaten Ciamis. Realisasi Luas Tanam, Panen, Produksi dan Produktivitas Tanaman Kubis. 2015.

Direktorat Jenderal Hortikultura. 2008. Membangun Hortikultura Berdasarkan Enam Pilar Pengembangan. http://hortikultura.go.id (diakses 22 Februari 2012).

Fuad, M. 2004. Pengantar Bisnis. Penerbit Gramedia.

Friady, 2012.Analisis Titik Impas Usahatani Cabe Merah. Jurnal Agribis. Vol. IV. No. 1.

Marsono dan Sigit. P. 2005.Pupuk Akar (Jenis \& Aplikasi). Penebar Swadaya. Jakarta. 
Jurnal Ilmiah Mahasiswa AGROINFO GALUH

Volume 3 Nomor 2, Januari 2017

Mulyono, 2007. Bercocok Tanam Kubis. Azka Mulia Media. Jakarta.

Naomi N, 2011.Analisi Titik Impas Usahatani Kubis. Jurnal EPP. Vol. No 1 : 28-32

Nazir, M. 2003. Metode Penelitian. Cetakan Keempat, Jakarta: Ghalia Indonesia

Rahardja. P. dan Manurung.M, 2008. Pengantar Ilmu Ekonomi (Mikro ekonomi dan Makroekonomi) Edisi Ketiga. Fakultas Ekonomi Universitas Indonesia. Jakarta.

Riyanti, 2014. Modul 1. Pendahuluan: Pengantar Usahatani.

Rahim dan Hastuti, 2007. Pengantar, Teori, dan Kasus Ekonomika Pertanian. Cetakan Kedua. Penebar Swadaya. Jakarta.

Husodo, 2004. Pertanian Mandiri. Jakarta. Penerbar Swadaya.

Sugiyono, 2009. Pengertian Teknik Sampling. Alfabeta. Bandung

Soekartawi. 2006. Analisis Usahatani. UI Press. Jakarta.

Suratiyah, 2006. Ilmu Usahatani. Penebar Swadaya. Jakarta.

2009. Ilmu Usahatani. Penebar Swadaya. Jakarta.

Wirartha, I. M. 2006. Metode Penelitian Sosial Ekonomi. Yogyakarta: ANDI 